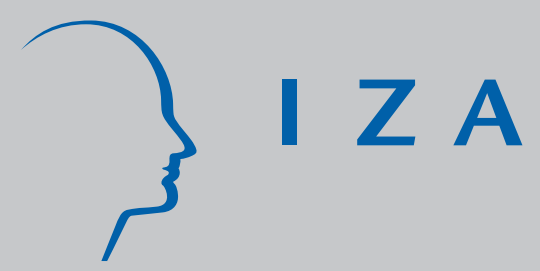

IZA DP No. 2436

The Influence of Wages on Parents' Allocations of Time to Child Care and Market Work in the United Kingdom

Charlene M. Kalenkoski

David C. Ribar

Leslie S. Stratton

November 2006 


\title{
The Influence of Wages on Parents' Allocations of Time to Child Care and Market Work in the United Kingdom
}

\author{
Charlene M. Kalenkoski \\ Ohio University \\ David C. Ribar \\ University of North Carolina at Greensboro \\ and IZA Bonn \\ Leslie S. Stratton \\ Virginia Commonwealth University \\ and IZA Bonn
}

Discussion Paper No. 2436

November 2006

\author{
IZA \\ P.O. Box 7240 \\ 53072 Bonn \\ Germany \\ Phone: +49-228-3894-0 \\ Fax: +49-228-3894-180 \\ E-mail: iza@iza.org
}

\begin{abstract}
Any opinions expressed here are those of the author(s) and not those of the institute. Research disseminated by IZA may include views on policy, but the institute itself takes no institutional policy positions.
\end{abstract}

The Institute for the Study of Labor (IZA) in Bonn is a local and virtual international research center and a place of communication between science, politics and business. IZA is an independent nonprofit company supported by Deutsche Post World Net. The center is associated with the University of Bonn and offers a stimulating research environment through its research networks, research support, and visitors and doctoral programs. IZA engages in (i) original and internationally competitive research in all fields of labor economics, (ii) development of policy concepts, and (iii) dissemination of research results and concepts to the interested public.

IZA Discussion Papers often represent preliminary work and are circulated to encourage discussion. Citation of such a paper should account for its provisional character. A revised version may be available directly from the author. 
IZA Discussion Paper No. 2436

November 2006

\begin{abstract}

\section{The Influence of Wages on Parents' Allocations of Time to Child Care and Market Work in the United Kingdom*}

We use time-diary data on couples with children from the 2000 United Kingdom Time Use Survey to examine the impacts of own and partner's wages on parents' provision of child care and market work on weekdays and on weekends and holidays. We find that increases in partners' wages increase women's primary care on all days and decrease their market work on weekdays, while increases in women's own wages increase their market work on weekdays. In contrast, men's time use is only responsive to their own wage on weekend days, when they reduce their market time and increase their primary child care time in response to higher wages.
\end{abstract}

JEL Classification: J1, J2

Keywords: $\quad$ time use, child care, wages

Corresponding author:

David C. Ribar

Department of Economics

University of North Carolina at Greensboro

P.O. Box 26165

Greensboro, NC 27402-6165

USA

E-mail: dcribar@uncg.edu

\footnotetext{
* An earlier version of this paper was presented at the 2006 North American Winter meetings of the Econometric Society and at the May 2006 meetings of the Society of Labor Economists. The authors thank Robert Lerman for helpful comments.
} 


\section{Introduction}

The wage and employment opportunities for women and men have changed tremendously in recent years, with women's wages and opportunities substantially improving. From 1988 through 2005, the employment rate for women aged 16-59 in the U.K. increased from 64 to 70 percent; over the same period real average gross weekly earnings for women employed full-time increased by 68 percent. ${ }^{1}$ While increased market opportunities give women more choice, more independence, and perhaps more bargaining power within households, there are concerns that these opportunities may have also contributed to deleterious outcomes for children by reducing the time that parents spend with children.

The theory relating time allocation decisions to wages does not yield clear predictions. In standard unitary preference models of household production, changes in own and partner's wages lead to income and substitution effects and ambiguous predictions about the directions of the relationships with the uses of time (Becker 1981). The relationships are even more complicated in models that allow for bargaining, such as the collective utility framework (Chiappori 1992 and Browning and Chiappori 1998) in which couples choose their time allocations to maximize a household utility function that is a weighted average of each partner's individual utility, where the weights depend on each partner's resources.

These ambiguous predictions have mixed implications for empirical work. On the one hand, the lack of strong or simple predictions makes it harder to test specific theories. On the other hand, the lack of clear predictions increases the need for empirical work to sort out the actual relationships. Predictions notwithstanding, wages remain important to all economic theories of household activities. In standard models, they represent an explicit price on market time and an implicit price on non-market time; they also represent potential resources to the 
household. In newer bargaining models, wages are an important determinant of individuals' bargaining power within the household. Pollak (2005), in particular, has made this argument supporting the use of wages rather actual labor market earnings in tests of these models. Finally, wages are a potential object of policy, whether directly though mechanisms such as the minimum wage and comparable worth requirements or indirectly through taxes, transfers, and subsidies.

Unfortunately, research that directly examines the effect of wages on child care time has been hampered by data limitations. Few data sets include accurate information on both market opportunities and household time use. However, we have access to an unusually rich data set, the 2000 United Kingdom Time Use Survey (UKTUS), which includes detailed time diary information along with questionnaire data on wages and other personal characteristics for all adult household members. Using these data we estimate gender-specific multivariate models of the time that parents in couple households each spend in primary child care activities, passive child care activities, and market work. The models include controls for both partners' predicted net wages. Because the adults in the UKTUS completed diaries on both weekdays and weekend days, our analyses are further able to distinguish between activities on different days of the week, giving us insights into the timing of activities.

The rest of this paper is organized as follows. The next section contains a brief review of the empirical literature. A discussion of the time use and questionnaire data used in our empirical analyses follows in section 3. Section 4 describes the wage predictions. Estimation results for parents' time use are reported in Section 5, and conclusions are offered in Section 6. 


\section{Literature Review}

Estimates of own- and cross-wage elasticities of labor supply for couple households abound (see, for example, Blundell's and MaCurdy's 1999 review). Most of the literature suggests that women's labor supply is more sensitive to changes in own and spouse's wages than men's labor supply. For example, a recent study by Devereux (2004) of 1980 and 1990 PUMS data from the U.S. found that labor supply among married women was modestly positively related to changes in their own wages and strongly negatively related to changes in their husbands' wages, while labor supply among married men was essentially unrelated to changes in either their own or their wives' wages. Similarly, an analysis of married British parents by Parera-Nicolau and Mumford (2005) found that mothers' labor supply was negatively related to changes in their partner's wages and that fathers' labor supply was only weakly related to changes in their wives' wages. However, the researchers reported a negative relation between mothers' labor supply and their own wages and, in contrast to much of the literature, a strong positive relation between fathers' labor supply and their own wages.

The bulk of the research on household labor supply has been based on recall questions regarding usual hours worked. With the increasing availability of time-diary data, researchers are revisiting these findings and also looking at the relationship between wages and other uses of time. One finding from the new surveys is that estimates of labor supply elasticities may be sensitive to the methods used to collect the underlying data. Klevmarken's (2005) analysis of the Swedish Household Panel Surveys revealed that own wage elasticities estimated using weekday time-diary data were larger than those estimated using retrospective annual work hours questions but similar to those estimated from previous-week recall questions. Within the time diaries, Klevmarken also found that the day of the week mattered, with own wage elasticities for 
weekdays being close to zero but elasticities for weekends being modestly negative for both men and women.

In contrast to the large number of labor supply studies, only a few studies have looked at the effects of husbands' and wives' wages on parents' child care time, as we propose to do here. ${ }^{2}$ Kooreman and Kapteyn (1987) used U.S. time-diary data on married couples from the 19751981 Time Use Longitudinal Panel and found that higher wages for fathers increased and higher wages for mothers reduced the time mothers spent on child care, although these results were statistically insignificant. They did not find a strong relationship between fathers' provision of care and either fathers' or mothers' wages. Maassen van den Brink and Groot (1997) looked at child care, other housework, and market work among working married and cohabiting mothers in the Netherlands. They found that mothers' child care and market work both increased in response to changes in their own wages, but that these uses of time were not significantly related to partners' wages. Hallberg and Klevmarken (2003) used Swedish data on dual-earner married and cohabiting couples and estimated models in which each parent's time spent in child care depended on his/her own wages and market hours, paid child care, and the partner's child care and work hours. They found that parents' provision of child care was not directly related to changes in their own wages. However, they found that child care time was negatively associated with own work hours and positively associated with partners' child care and work hours.

In a study framed as a test of household bargaining power, Friedberg and Webb (2005) examined data from the ATUS to see how couples' time use varied with their relative wages. They reported that wives with relatively high wages enjoyed more leisure time on weekends and spent less time doing chores than wives with low relative wages. Wives with high relative wages 
also spent less time on weekday child care. Husbands' time use was less sensitive than wives' to changes in wages.

We use recent time-diary data for the UK to calculate the effects of own and partner's wages on the time mothers and fathers spend in child care and market work. In light of previous sociological research (e.g., Nock and Kingston 1988) and our own research (Kalenkoski et al. 2005) that shows that different intensities of child care activities may be important, we distinguish between time spent in primary and passive care activities. Following Klevmarken (2005) and Friedberg and Webb (2005), our analyses also distinguish between time use on weekdays and weekends/holidays.

\section{Data}

The data for our empirical analyses come from the United Kingdom Time Use Survey. The UKTUS is a national, household-based study with multiple questionnaire and time diary components that was conducted in 2000-2001. Each household in the study completed one questionnaire that provided information on household-specific characteristics such as income and family composition. Each household member then completed another questionnaire providing information on personal characteristics such as education, employment status, and earnings. Time diaries were also collected for each individual age 8 and older; these identified the primary or secondary nature of activities, the location of each activity, and who else was present during each activity for every 10-minute interval during two 24-hour periods: one weekday and one weekend day. In sum, the UKTUS obtained 20,981 time diaries from 11,664 people living in 6,414 households.

The key explanatory variables in our study are the net, or after-tax, hourly wages 
available to both the parent and his or her partner in the household. We construct our wage measures by dividing net monthly earnings by usual paid hours as reported in the individual questionnaire component of the UKTUS. While the approach is conceptually straightforward, two complications arise. The first is that the underlying earnings information is not observed for everyone in the UKTUS. The second is that wages may be endogenous. For example, a parent may accept a lower wage as a compensating differential for more flexibility and autonomy in the uses of time (e.g., for more flexible work hours, a more liberal leave policy, or a shorter commute). Because of the problems of missing and endogenous wage data, we predict wages for all of the men and women in our time-use analysis.

We use two samples of the UKTUS for our analysis. The first is a general sample of adults that is used to estimate selectivity-corrected wage models and to predict potential wages, while the second is a narrower sample of parents in couple households with time-diary information that is used to analyze time use as a function of those predicted wages. Both samples exclude persons who fail to complete both a household and an individual survey, married and cohabiting individuals with partners who fail to complete an individual survey, residents of Northern Ireland (because these data fail to include information on unemployment rate or urbanicity), persons who are younger than age 16 or older than retirement age (65 for men, 60 for women), persons who are enrolled in school, and persons who fail to identify their relationships with each household member. A small number of individuals who are in same-sex relationships or who fail to provide information on other explanatory variables, such as educational attainment, are also excluded. These exclusions result in a general sample of adults used to predict wages that includes 3,330 women and 3,190 men.

The time-diary sample is further restricted to include only married or cohabiting 
individuals with children under the age of 18 . Time diaries identifying fewer than five activity spells or with more than one hour unaccounted for are also excluded. These exclusions yield a time-diary sample of 1,056 households with 1,062 women and 1,023 men completing 2,012 and 1,931 diaries, respectively.

We focus on three uses of time: primary child care, passive child care, and market work. Primary child care activities are defined here to include physical care, teaching, playing, talking, escorting, and transporting children living in one's own household (care for children living in other households is excluded) as well as transportation to and from educational activities. Our measure of passive care is constructed by summing up all time spent with children aged 14 and under that is not spent in child care as a primary activity, excluding time spent sleeping, working in the market, or in certain personal care activities. ${ }^{3}$ Market work activities are specified to include first and second jobs, travel related to work (though not commuting time), and lunch and coffee breaks.

The questionnaire components of the UKTUS include many variables that we use as controls in our models. Among these are measures for the parents' marital status, education, age, and health status. There are also controls for age of the youngest child (categorized into 0-3, 4-6, 7-11, or 12-17 years of age), the total number of children, the number of children aged 12-17 (who could themselves provide child care), the number of other adults in the household, and dummies to identify households located in a rural area, households with a disabled child, and households with unearned household income. In addition, there are controls for the region of residence, the season that the diary was completed, and the type of day (weekday, weekend or holiday) of the diary report. Means and standard deviations for the time use outcomes and the full set of explanatory measures for the time-diary sample are reported separately by gender in 
Table 1. Descriptive statistics for the wage sample, also calculated separately by gender, are reported in Appendix Table A1.

\section{Predicting Wages}

As discussed above, we use a sample of 3,330 women and 3,190 men to analyze employment and wages and to subsequently predict net wages for the individuals in our time-use sample. A substantial portion of the people in our general sample do not report the information needed to construct the wage measures. The information may be missing for two reasons. First, there is the matter of employment itself -992 women and 623 men in the sample do not work and therefore have no earnings to report. Second, there is some item non-response among those who do work. In addition to the observations that are lost for these reasons, we purposefully exclude some other wage reports. Specifically, we drop earnings data for people who are selfemployed as their incomes may reflect returns to capital as well as returns to labor. We also drop observations where the calculations of the net hourly wage are unreasonably high or low. The exclusions for missing data, self-employment, and out-of-range values further reduce the wage sample by 564 women and 964 men, leaving net wage observations for 1,774 women and 1,603 men.

As there are two distinct mechanisms-non-employment and incomplete or unusable reporting - that lead to missing wage data, we use a two-stage estimation procedure that addresses potential biases from these two sources of selectivity. In the first stage of this procedure, we jointly estimate gender-specific probit models of whether people worked and, conditional on their working, of whether they provided usable earnings information. In the second stage, we estimate gender-specific, selectivity-adjusted log net wage regressions, 
following Tunali's (1986) bivariate correction method.

Coefficient estimates and standard errors from the first-stage conditional bivariate probit models are reported in Appendix Table A2. Identification in these models requires that we include some variables in the (conditioning) employment probit that are not included in the (conditional) earnings reporting probit. We expect that characteristics of the partner, including his or her age, education, potential experience, and health, will influence employment outcomes but not reporting behavior, and we specify the models accordingly. For men and women, estimation reveals that the partner's education and health are particularly powerful determinants of one's own employment. The remaining variables, which are included in both equations, include measures for the person's own education, age, potential experience, and health status; dummy variables for region of residence and residence in a rural area; dummy variables to identify cohabiting and single persons and those with some nonlabor income; a measure of the local unemployment rate; dummy controls for the season of the year; and household composition measures that indicate the age of the youngest child, the number of children in the household, the number of children age 12-17, the number of other adults, and the presence of a disabled child.

The results from the employment models are fairly standard, with the unemployment rate, education, age, and health status being significant predictors for women and men. The presence of young children is an additional significant predictor of women's employment, while relationship status is an important predictor of men's employment. There are fewer significant predictors in the conditional probits for reporting earnings. Education and the number of adults in the household are each significant predictors of reporting for men and women.

The second stage log net wage specifications include all the variables in the reporting probits as well as two correction terms to account for selectivity associated with employment and 
the availability of a useful wage report. Results, reported in Appendix Table A3, indicate that education, potential experience, and geographic location are significant predictors of log net wages. Our time use equations incorporate a measure of each partner's predicted log net wage not conditioned on employment or wage reporting status in order to gauge the impact of the each partner's market value of time on household time allocation decisions. To identify the effects of wages on time use, we exclude information on own and partner's education and potential experience, the local unemployment rate, and the region of residence from the time use models. Education and experience are assumed to impact market productivity, while the unemployment rate and geographic controls are assumed to capture labor market conditions. ${ }^{4}$ We also substitute information on the season of year for which the time diary is completed for the season of year for which the wage is reported and incorporate a dummy variable to identify public holidays in the weekend/holiday equations.

\section{Multivariate Analyses of Parents' Time Use}

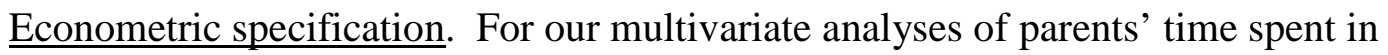
primary child care, passive child care, and market work, we face two further statistical challenges. The first is that the reported times spent in each activity are non-negative with substantial numbers of observations massed at zero. Thus, we need multivariate models that are appropriate for censored dependent variables. The second challenge involves the estimation of standard errors for the model coefficients, which must be adjusted not only for the use of predicted wage variables but also for the use of repeated observations (clustering) for individuals and within households.

To address the censoring in the dependent variables, we estimate standard maximum 
likelihood Tobit models of the different types of time use. One way to motivate the Tobit specification is to assume that people have preferred notional, or latent, amounts of time that they would like to spend in given activities (time that may be positive or negative). The actual time that people can spend in any activity must, however, be non-negative. Thus, we observe the latent time if it is non-negative and a censored value of zero otherwise. Although Tobit models address censoring, they also impose strong restrictions on the relationship between the discrete decision of whether to participate in an activity and the marginal decision of how much time to spend conditional on participation. The models are also sensitive to assumptions regarding the distribution of unobserved determinants of the outcome variable. If either of these specification assumptions is incorrect, estimates from the Tobit model will be biased and inconsistent. For example, Mroz (1987) has shown that estimates of married women's labor supply are sensitive to these types of specification issues.

Because of the fragility of the Tobit model, we also estimate Censored Least Absolute Deviations (CLAD) specifications of our time use models. The CLAD procedure places much weaker restrictions on the distribution of the unobserved components of the model. However, the procedure is less efficient than the Tobit approach and can only be applied in situations where the majority of observations for the dependent variable are uncensored.

To estimate the standard errors in the Tobit and CLAD models, we employ a bootstrapping procedure. In this procedure, we first draw 200 equally-sized random samples of households_-including all of the employment, wage, and time diary reports for each household—with replacement from our original general sample of households. For each random sample, we then apply our two-stage wage estimation procedure, use the resulting estimates to predict wages and finally estimate censored regression models of time use. This generates 200 
sets of coefficient estimates, which we use as an approximation of the sampling distribution of the estimates.

Tobit estimation results. Coefficient estimates and bootstrapped standard errors for the Tobit models of time use are reported in Table 2. Marginal effects calculated at the sample means (as reported in Table 1) are reported in Table 3. Both tables have the following format. The first four columns list results for the primary care models for mothers on non-holiday weekdays, mothers on weekends or holidays, fathers on non-holiday weekdays, and fathers on weekends or holidays. The middle four columns list similarly arranged results for time spent in passive care, and the final four columns report results for time spent in market work. Coefficient estimates and marginal effects are presented for the log net wages for the person and partner, three indicators for the age of the youngest child, counts of the total number of children and the number of children aged 12-17, an indicator for a disabled child, indicators for health problems for either parent, a count of the number of adults, and an indicator for cohabitation status. In addition to these variables, the models also include indicators for unearned income and rural residence, controls for season of the year, and quadratic controls for own and partner's age. For brevity, we do not report estimates or marginal effects for these other controls; detailed results are available upon request.

The focus of our analysis is on the associations that own and partners' potential net wages have with time use. Estimates of these associations are reported in the first two rows of Table 2. The estimates indicate that women in couple households in the U.K. increase their primary child care time when their spouses' or partners' wages increase. The implied crosswage elasticities, evaluated at the sample means, are 0.4 for weekday primary care and 0.6 for weekend/holiday care. A more surprising, though tenuous, finding is that women's provision of 
primary care in the U.K. is also weakly positively associated with increases in their own wages. Men's weekday provision of primary care is unrelated to changes in their own wages and only weakly (positively) related to changes in their partners' wages. On weekends and holidays, however, men's time spent in primary care is significantly positively associated with own wages. The implied elasticity is 0.5 .

There are no statistically significant wage coefficients in the passive care models. One reason for this may be that passive care times are highly variable, so even though there are a few moderately-sized coefficients, they are accompanied by large standard errors. The only results that approach statistical significance are the positive coefficients for own wages for weekend passive care among women with a $p$-value of .17 and partners' wages for passive care among men with a $p$-value of .13; the implied elasticities for these two associations are each approximately 0.2 .

In the market work models we find, like much of the extant literature, that women significantly increase their market time as their potential wages rise and decrease their market time as their partners' potential wages rise - but only on weekdays. The implied elasticities are 1.2 and -1.0. Neither own nor partner's potential wage affects women's market work time on weekends. The patterns for men are different. Men's weekday market work time does not appear to respond to changes in their own or their partners' net wages. However, men's weekend and holiday market work does appear to be negatively related to changes in their own wages and possibly negatively related $(p$-value $=.16)$ to changes in their partners' wages. The implied elasticities for these two outcomes are -0.7 and -0.5 .

Other results indicate that time use is strongly affected by the age and number of children in the household, as well as the presence of a disabled child. The age of the youngest child in the 
household has a large and significant positive effect on primary and passive child care time for both parents on all days. The presence of younger children has a substantially larger effect than older children as, for example, women's weekday primary child care time is 143 minutes larger when the youngest child is age 0-3 versus age 12-17 (the base case). Passive child care time is universally more responsive in terms of absolute time spent than primary child care time and more responsive on weekends than on weekdays, but this does not necessarily translate to a larger relative responsiveness as more time is spent on passive child care than on primary child care. Similarly, while women generally are more responsive in an absolute time sense than men to the age of the youngest child, they generally also spend more time on child care than men. This makes the small magnitude of the gender differential for passive child care time on weekends all the more notable as it suggests that in this case men are somewhat more responsive in relative terms.

By contrast, the age of the youngest child only has a significant impact on market time for women with children age $0-3$. These women spend over three hours less in the market on weekdays, and this difference is statistically significant. However, both men and women report less time in employment and more time in passive childcare on weekdays the more children there are in the household. The number of children is also positively associated with women's primary child care time on weekdays, though the effect is small at only 12 minutes for an additional child. The presence of a disabled child increases the time that women spend in weekday and weekend primary care by almost an hour; it also reduces the amount of time that women spend in weekday market work by over four hours. Disabled children are not significantly associated with men's provisions of primary care or market work; however, disabled children are positively associated with men's weekday passive care, which rises by about an hour and a half. In general, 
these results are consistent with greater care needs for disabled children.

Health problems on the part of the respondent or his/her partner also impact time use. Own health problems significantly and substantially decrease market work time for women on weekdays (about two hours) and for men on all days of the week (over four hours on weekdays and about one and a half hours on weekends). Men with health problems also report more time on primary child care during weekdays, but the effect is small at 13 minutes. Partner's health status is not a significant determinant of one's own provision of primary or passive child care. Having a partner in poor health does significantly decrease weekday market work for women (by over 2.5 hours) but not for men.

When we examine the results for older children and other adults in the household, we find that the number of children age 12-17 decreases by a small amount women's primary child care time on weekdays. While this result is consistent with older children serving as substitute caregivers, we also find that children 12-17 increase the time women report spending on passive child care on weekends. This latter finding may reflect the different types of care required by older and younger children rather than caregiving on the part of older children. Other adults in the household have a more substantial impact on time use. The more other adults, the less time either parent spends on passive child care on any day with only the effect for men on weekdays being insignificant. Women also report spending a little less time on primary child care on weekends and substantially more time on the job on weekdays when there are other adults present. In general, the presence of other adults does appear to reduce parental time in both primary and passive child care.

Cohabiting parents of both genders spend a little less time on primary child care on weekdays relative to their married counterparts. Cohabiting parents also spend less time in 
passive care, though the estimated associations are only significant for men's weekend care. Cohabitation status is not consistently or significantly associated with market work.

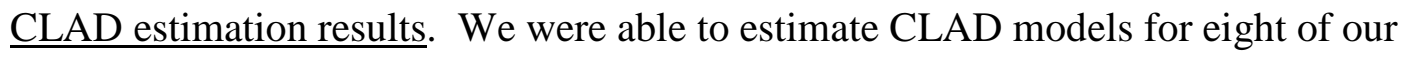
activity $\times$ gender $\times$ day-of-week outcomes. For four of the outcomes-men's weekday and weekend primary care and women's and men's weekend market work-there were too few positive observations to obtain estimates. As expected given the lower efficiency of the CLAD procedure, there were also fewer significant findings among the models that we could estimate. Coefficient estimates and standard errors from the CLAD models of time use are reported in Table 4.

In the CLAD models for women's weekday market work, the significant positive coefficient for own wages and the significant negative coefficient for partners' wages from the Tobit models are reproduced. The positive coefficients on partners' wages in the women's weekday and weekend primary care models are also reproduced, though not at conventional significance levels (the $p$-values are .14 and .20 , respectively). The significant positive coefficients for young children on mothers' primary care and both parents' passive care are also reproduced. Many of the other significant coefficients from the Tobit model are also significant with similar signs in the CLAD specifications. A few of these coefficients lose their significance in the CLAD models, but none reverses sign. The similarity of the results across the alternative specifications suggests that the restrictions of the Tobit model are not unduly altering our findings.

\section{Conclusion}

In this paper we use time-diary data on couples with children from the 2000 United 
Kingdom Time Use Survey to investigate the effects of own and partner's net wages on the time parents spend in primary child care, passive child care, and market work. We find that, consistent with the previous literature, women increase their market time when their wage increases and decrease their market work time as their partner's wage increases. However, we find that this is true only on weekdays; there are no significant wage effects on women's market work time on weekends. Also consistent with much of the previous literature, we find that men are relatively insensitive to both their own and their partner's wages. We find no wage effects on men's weekday market time, but find that men with high potential wages spend significantly less time on market work on weekends.

With respect to child care time, we find that women whose partners have higher potential wages spend significantly more time on primary child care on all days and men with higher wages spend more time on primary child care on weekends. Women with higher potential wages may spend more time on primary child care, too, but this effect is not significant at conventional levels. We also find weak evidence that increases in women's wages are positively associated with their own and their spouses' or partners' weekend provision of passive care. Thus, we do not find cross-section evidence to support the proposition that women's rising potential wages have had a deleterious effect on child care time in the U.K.; rather, the opposite appears to have occurred. In addition, we find that rising wages among men in the U.K. may have contributed to increases in women's and men's provision of primary child care. 


\section{References}

Bianchi, Suzanne M. "Maternal Employment and Time with Children: Dramatic Change or Surprising Continuity?” Demography 37:4 (November 2000), 401-14.

Becker, Gary S. A Treatise on the Family. Cambridge, MA: Harvard University Press, 1981.

Blundell, Richard and Thomas MaCurdy. "Labor Supply: a Review of Alternative Approaches." In Handbook of Labor Economics volume 3A, edited by Orley Ashenfelter and David Card. Amsterdam: Elsevier, 1999, pp. 1559-1695.

Browning, Martin, and Pierre-Andre Chiappori. "Efficient Intra-Household Allocations: A General Characterization and Empirical Tests.” Econometrica 66 (November 1998), $1241-78$.

Bryant, W. Keith and Cathleen D. Zick. "An Examination of Parent-Child Shared Time." Journal of Marriage and the Family 58:1 (February 1996), 227-37.

Chiappori, Pierre-Andre. "Collective Labor Supply and Welfare." Journal of Political Economy 100 (June 1992), 437-67.

Devereux, Paul J. "Changes in Relative Wages and Family Labor Supply." Journal of Human Resources 39:3 (Summer 2004), 696-722.

Friedberg, Leora and Anthony Webb. "The Chore Wars: Household Bargaining and Leisure Time.” Unpublished manuscript. Charlottesville, VA: University of Virginia, November 2005.

Hallberg, Daniel and Anders Klevmarken, “Time for Children: A Study of Parent's Time Allocation," Journal of Population Economics 16:2 (May 2003), 205-26. 
Kalenkoski, Charlene M., David C. Ribar and Leslie S. Stratton. "Parental Child Care in SingleParent, Cohabiting, and Married-Couple Families: Time Diary Evidence from the United Kingdom.” American Economic Review 95:2 (May 2005), 194-8.

Klevmarken, N. Anders. "Estimates of a labour supply function using alternative measures of hours of work." European Economic Review 49:1 (January 2005), 55-73.

Kooreman, Peter and Arie Kapteyn, “A Disaggregated Analysis of the Allocation of Time within the Household.” Journal of Political Economy 95:2 (April 1987), 223-249.

Maassen van den Brink, Henriëtte and Wim Groot. "A Household Production Model of Paid Labor, Household Work and Child Care.” De Economist 145:3 (1997), 325-43.

Mroz, Thomas. "The Sensitivity of an Empirical Model of Married Women's Hours of Work to Economic and Statistical Assumptions.” Econometrica 55:4 (July 1987), 765-99.

Nock, Steven L. and Paul W. Kingston. “Time with Children: The Impact of Couples' WorkTime Commitments.” Social Forces 67:1 (September 1988), 59-85.

Pollak, Robert A. "Bargaining Power in Marriage: Earnings, Wage Rates and Household Production.” National Bureau of Economic Research, Working Paper No. 11239 (March 2005).

Tunali, Insan. "A General Structure for Models of Double-Selection and an Application to a Joint Migration/Earnings Process with Remigration," Research in Labor Economics 8B (1986), 235-82. 


\section{Table 1. Descriptive statistics for variables in time-use samples}

\begin{tabular}{|c|c|c|c|c|}
\hline & \multicolumn{2}{|c|}{ Women } & \multicolumn{2}{|c|}{ Men } \\
\hline & Mean & Std. Err. & Mean & Std. Err. \\
\hline \multicolumn{5}{|l|}{ Outcome Measures: } \\
\hline Minutes in Primary Child Care - Weekday & 104.72 & $(109.79)$ & 39.17 & $(65.00)$ \\
\hline Minutes in Primary Child Care - Weekend/Holiday & 82.50 & $(105.48)$ & 47.85 & $(76.33)$ \\
\hline Minutes in Passive Child Care - Weekday & 298.89 & $(243.04)$ & 177.25 & $(187.83)$ \\
\hline Minutes in Passive Child Care - Weekend/Holiday & 404.71 & $(295.90)$ & 338.15 & $(290.22)$ \\
\hline Minutes in Market Work - Weekday & 203.93 & $(222.68)$ & 414.54 & $(247.42)$ \\
\hline Minutes in Market Work - Weekend/Holiday & 56.35 & $(141.26)$ & 108.43 & $(209.34)$ \\
\hline \multicolumn{5}{|l|}{ Explanatory Variables: } \\
\hline Cohabiting & 0.13 & $(0.34)$ & 0.14 & $(0.34)$ \\
\hline Age & 37.32 & $(7.71)$ & 39.79 & $(8.15)$ \\
\hline Respondent has a health problem & 0.10 & $(0.29)$ & 0.09 & $(0.28)$ \\
\hline Youngest child age $0-3$ & 0.32 & $(0.47)$ & 0.32 & $(0.47)$ \\
\hline Youngest child age 4-6 & 0.14 & $(0.35)$ & 0.15 & $(0.35)$ \\
\hline Youngest child age 7-11 & 0.28 & $(0.45)$ & 0.27 & $(0.44)$ \\
\hline Total number of children & 1.85 & $(0.86)$ & 1.85 & $(0.86)$ \\
\hline Number of children $12-17$ & 0.65 & $(0.82)$ & 0.63 & $(0.80)$ \\
\hline Disabled child & 0.02 & $(0.14)$ & 0.02 & $(0.13)$ \\
\hline Number of adults & 0.18 & $(0.50)$ & 0.17 & $(0.48)$ \\
\hline Household receives unearned income & 0.25 & $(0.43)$ & 0.25 & $(0.43)$ \\
\hline Rural & 0.45 & $(0.50)$ & 0.45 & $(0.50)$ \\
\hline Winter & 0.21 & $(0.41)$ & 0.21 & $(0.41)$ \\
\hline Spring & 0.26 & $(0.44)$ & 0.27 & $(0.44)$ \\
\hline Summer & 0.25 & $(0.43)$ & 0.25 & $(0.43)$ \\
\hline Partner's age & 39.94 & $(8.21)$ & 37.1569 & (7.6619) \\
\hline Partner has a health problem & 0.09 & $(0.28)$ & 0.0906 & $(0.2872)$ \\
\hline Number of observations & 2012 & & 1931 & \\
\hline
\end{tabular}

Note: Descriptive statistics calculated from the UKTUS. 
Table 2. Coefficient Estimates from Tobit Models of Time-Use

\begin{tabular}{|c|c|c|c|c|c|c|c|c|c|c|c|c|c|c|c|}
\hline \multirow{4}{*}{$\frac{\text { Variable }}{\text { Own potential log wage }}$} & \multicolumn{7}{|c|}{ Daily Minutes of Primary Child Care Time } & \multicolumn{4}{|c|}{ Daily Minutes of Passive Child Care Time } & \multicolumn{4}{|c|}{ Daily Minutes of Market Work Time } \\
\hline & \multicolumn{4}{|c|}{ Women } & \multicolumn{3}{|c|}{ Men } & \multicolumn{2}{|c|}{$\begin{array}{l}\text { Women } \\
\text { Weekday Weekend }\end{array}$} & \multicolumn{2}{|l|}{ Men } & \multicolumn{2}{|c|}{ Women } & \multicolumn{2}{|l|}{ Men } \\
\hline & Weekda & & Weeken & & Weekda & & Weekend & Weekday & Weekend & Weekday & Weekend & Weekday & Weekend & Weekday & Weekend \\
\hline & $\begin{array}{c}19.2 \\
(16.5)\end{array}$ & & $\begin{array}{c}21.8 \\
(23.2)\end{array}$ & & $\begin{array}{c}0.3 \\
(23.8)\end{array}$ & & $\begin{array}{c}50.2 \\
(26.9)\end{array}$ & $\begin{array}{c}23.1 \\
(40.0)\end{array}$ & $\begin{array}{c}78.0 \\
(57.2)\end{array}$ & $\begin{array}{l}-48.0 \\
(48.0)\end{array}$ & $\begin{array}{c}79.3 \\
(77.4)\end{array}$ & $\begin{array}{l}238.4 * * * \\
(65.9)\end{array}$ & $\begin{array}{c}-25.4 \\
(144.2)\end{array}$ & $\begin{array}{c}21.6 \\
(57.7)\end{array}$ & $\begin{array}{l}-231.0 * \\
(136.4)\end{array}$ \\
\hline Partner's potential log wage & $\begin{array}{c}47.0 \\
(22.0)\end{array}$ & $* *$ & $\begin{array}{c}76.1 \\
(34.8)\end{array}$ & $* *$ & $\begin{array}{c}11.6 \\
(20.5)\end{array}$ & & $\begin{array}{c}11.1 \\
(21.8)\end{array}$ & $\begin{array}{c}-0.9 \\
(52.0)\end{array}$ & $\begin{array}{c}16.2 \\
(60.4)\end{array}$ & $\begin{array}{c}36.2 \\
(40.1)\end{array}$ & $\begin{array}{c}91.6 \\
(61.1)\end{array}$ & $\begin{array}{c}-182.0 * * \\
(78.5)\end{array}$ & $\begin{array}{c}187.4 \\
(166.3)\end{array}$ & $\begin{array}{c}12.0 \\
(51.0)\end{array}$ & $\begin{array}{l}-169.2 \\
(121.0)\end{array}$ \\
\hline Youngest child age $0-3$ & $\begin{array}{l}178.9 * \\
(18.3)\end{array}$ & $* * *$ & $\begin{array}{l}227.3 \\
(26.2)\end{array}$ & $* * *$ & $\begin{array}{l}137.2 \\
(21.4)\end{array}$ & *** & $\begin{array}{l}165.6 * * * \\
(21.4)\end{array}$ & $\begin{array}{l}324.1 * * * \\
(45.8)\end{array}$ & $\begin{array}{l}410.8 * * * \\
(56.3)\end{array}$ & $\begin{array}{l}245.3 * * * \\
(45.6)\end{array}$ & $\begin{array}{l}430.0 * * * \\
(60.5)\end{array}$ & $\begin{array}{c}-191.9 * * * \\
(67.3)\end{array}$ & $\begin{array}{l}-172.9 \\
(139.7)\end{array}$ & $\begin{array}{c}8.0 \\
(52.4)\end{array}$ & $\begin{array}{c}82.4 \\
(124.2)\end{array}$ \\
\hline Youngest child age 4-6 & $\begin{array}{l}120.8 \text { * } \\
(16.3)\end{array}$ & $* * *$ & $\begin{array}{l}146.0 \\
(22.1)\end{array}$ & $* * *$ & $\begin{array}{l}104.4 \\
(18.0)\end{array}$ & & $\begin{array}{l}104.1 * * * \\
(18.5)\end{array}$ & $\begin{array}{l}200.6 \text { *** } \\
(45.6)\end{array}$ & $\begin{array}{l}397.3 * * * \\
(57.2)\end{array}$ & $\begin{array}{l}196.7 \text { *** } \\
(41.0)\end{array}$ & $\begin{array}{l}426.8 * * * \\
(56.0)\end{array}$ & $\begin{array}{c}-2.5 \\
(69.6)\end{array}$ & $\begin{array}{c}15.6 \\
(126.1)\end{array}$ & $\begin{array}{c}54.3 \\
(51.9)\end{array}$ & $\begin{array}{c}74.6 \\
(118.8)\end{array}$ \\
\hline Youngest child age 7-11 & $\begin{array}{c}72.6 * \\
(12.0)\end{array}$ & *** & $\begin{array}{c}83.5 \\
(16.8)\end{array}$ & $* * *$ & $\begin{array}{c}67.8 \\
(14.3)\end{array}$ & $* * *$ & $\begin{array}{l}66.0 * * * \\
(15.5)\end{array}$ & $\begin{array}{l}217.2 * * * \\
(34.9)\end{array}$ & $\begin{array}{l}321.6 * * * \\
(47.0)\end{array}$ & $\begin{array}{l}181.6 * * * \\
(34.0)\end{array}$ & $\begin{array}{l}378.1 \text { *** } \\
(46.7)\end{array}$ & $\begin{array}{l}-11.9 \\
(54.1)\end{array}$ & $\begin{array}{l}-62.9 \\
(95.4)\end{array}$ & $\begin{array}{c}33.9 \\
(37.2)\end{array}$ & $\begin{array}{l}-15.7 \\
(90.9)\end{array}$ \\
\hline Number of children & $\begin{array}{l}15.6 * \\
(5.7)\end{array}$ & *** & $\begin{array}{c}1.1 \\
(7.5)\end{array}$ & & $\begin{array}{l}5.0 \\
(6.7)\end{array}$ & & $\begin{array}{l}-1.3 \\
(6.4)\end{array}$ & $\begin{array}{l}50.8 \text { *** } \\
(13.8)\end{array}$ & $\begin{array}{c}18.2 \\
(16.2)\end{array}$ & $\begin{array}{l}26.0 * * \\
(12.7)\end{array}$ & $\begin{array}{c}8.0 \\
(19.1)\end{array}$ & $\begin{array}{l}-69.3 * * \\
(27.9)\end{array}$ & $\begin{array}{l}-58.3 \\
(42.6)\end{array}$ & $\begin{array}{l}-38.3 * * \\
(18.4)\end{array}$ & $\begin{array}{c}5.0 \\
(37.2)\end{array}$ \\
\hline Disabled child & $\begin{array}{c}65.5 \\
(20.7)\end{array}$ & $* * *$ & $\begin{array}{c}53.3 \\
(22.3)\end{array}$ & & $\begin{array}{l}-14.4 \\
(54.1)\end{array}$ & & $\begin{array}{c}6.1 \\
(23.0)\end{array}$ & $\begin{array}{c}64.2 \\
(53.5)\end{array}$ & $\begin{array}{c}25.1 \\
(74.3)\end{array}$ & $\begin{array}{l}129.5 * * \\
(55.5)\end{array}$ & $\begin{array}{c}-2.1 \\
(75.3)\end{array}$ & $\begin{array}{c}-271.7 * * * \\
(91.6)\end{array}$ & $\begin{array}{c}63.8 \\
(258.3)\end{array}$ & $\begin{array}{r}-153.4 \\
(98.2)\end{array}$ & $\begin{array}{c}200.4 \\
(164.9)\end{array}$ \\
\hline Respondent has a health problem & $\begin{array}{c}9.5 \\
(11.1)\end{array}$ & & $\begin{array}{c}9.3 \\
(13.4)\end{array}$ & & $\begin{array}{c}26.7 \\
(16.1)\end{array}$ & $*$ & $\begin{array}{c}3.2 \\
(19.7)\end{array}$ & $\begin{array}{l}-25.8 \\
(30.6)\end{array}$ & $\begin{array}{l}-23.5 \\
(39.3)\end{array}$ & $\begin{array}{c}14.1 \\
(36.1)\end{array}$ & $\begin{array}{c}60.9 \\
(51.3)\end{array}$ & $\begin{array}{c}-144.2 * * * \\
(53.8)\end{array}$ & $\begin{array}{l}-20.1 \\
(93.8)\end{array}$ & $\begin{array}{c}-312.3 * * * \\
(51.2)\end{array}$ & $\begin{array}{l}-327.7 * * * \\
(106.1)\end{array}$ \\
\hline Partner has a health problem & $\begin{array}{c}5.6 \\
(16.6)\end{array}$ & & $\begin{array}{c}-9.0 \\
(16.1)\end{array}$ & & $\begin{array}{c}5.6 \\
(11.0)\end{array}$ & & $\begin{array}{c}10.8 \\
(13.2)\end{array}$ & $\begin{array}{l}-23.3 \\
(37.0)\end{array}$ & $\begin{array}{l}-29.9 \\
(46.4)\end{array}$ & $\begin{array}{l}-31.6 \\
(26.7)\end{array}$ & $\begin{array}{c}15.8 \\
(44.3)\end{array}$ & $\begin{array}{c}-169.2 * * * \\
(63.5)\end{array}$ & $\begin{array}{l}-61.3 \\
(95.2)\end{array}$ & $\begin{array}{l}-24.3 \\
(40.3)\end{array}$ & $\begin{array}{c}9.7 \\
(77.9)\end{array}$ \\
\hline Number of children age $12-17$ & $\begin{array}{r}-16.4 \\
(7.4)\end{array}$ & $* *$ & $\begin{array}{c}2.0 \\
(9.8)\end{array}$ & & $\begin{array}{c}6.1 \\
(9.0)\end{array}$ & & $\begin{array}{l}-0.4 \\
(8.9)\end{array}$ & $\begin{array}{c}-2.4 \\
(18.6)\end{array}$ & $\begin{array}{l}45.0 * \\
(23.8)\end{array}$ & $\begin{array}{c}13.8 \\
(18.3)\end{array}$ & $\begin{array}{c}28.2 \\
(26.6)\end{array}$ & $\begin{array}{c}40.2 \\
(31.5)\end{array}$ & $\begin{array}{c}17.1 \\
(51.3)\end{array}$ & $\begin{array}{c}-6.7 \\
(21.7)\end{array}$ & $\begin{array}{c}54.3 \\
(50.1)\end{array}$ \\
\hline Number of adults & $\begin{array}{l}-5.9 \\
(7.6)\end{array}$ & & $\begin{array}{l}-23.4 \\
(11.3)\end{array}$ & & $\begin{array}{l}-9.8 \\
(9.8)\end{array}$ & & $\begin{array}{c}-6.9 \\
(12.3)\end{array}$ & $\begin{array}{l}-44.1 * * \\
(21.6)\end{array}$ & $\begin{array}{c}-105.4 * * * \\
(29.3)\end{array}$ & $\begin{array}{l}-21.0 \\
(19.3)\end{array}$ & $\begin{array}{c}-101.2 \text { *** } \\
(32.8)\end{array}$ & $\begin{array}{l}-67.1 * * \\
(33.9)\end{array}$ & $\begin{array}{l}-38.9 \\
(57.2)\end{array}$ & $\begin{array}{c}-9.7 \\
(21.8)\end{array}$ & $\begin{array}{l}-13.9 \\
(55.5)\end{array}$ \\
\hline Cohabiting & $\begin{array}{l}-21.0 \\
(11.4)\end{array}$ & * & $\begin{array}{c}-5.9 \\
(13.4)\end{array}$ & & $\begin{array}{l}-19.8 \\
(10.6)\end{array}$ & * & $\begin{array}{l}-13.0 \\
(14.9)\end{array}$ & $\begin{array}{l}-36.5 \\
(23.0)\end{array}$ & $\begin{array}{l}-41.7 \\
(30.8)\end{array}$ & $\begin{array}{l}-28.3 \\
(24.0)\end{array}$ & $\begin{array}{l}-54.2 * \\
(32.9)\end{array}$ & $\begin{array}{c}7.1 \\
(47.5)\end{array}$ & $\begin{array}{l}-49.7 \\
(86.3)\end{array}$ & $\begin{array}{l}-52.8 \\
(32.1)\end{array}$ & $\begin{array}{c}69.2 \\
(67.3)\end{array}$ \\
\hline
\end{tabular}

Notes: Table reports selected coefficients and bootstrapped standard errors (in parentheses) from Tobit models of time use. Estimated using data from the UKTUS.

Other variables included in all the specifications were quadratics in both own and partner's age, a dummy indicating household receipt of nonlabor income, a dummy indicating

residence in a rural area, and seasonal indicators. A dummy variable identifying holidays is included in the weekend specifications.

* Significant at the $10 \%$ level, ** Significant at the $5 \%$ level, *** Significant at the $1 \%$ level. 
Table 3. Marginal Effects from Tobit Models of Time Use

\begin{tabular}{|c|c|c|c|c|c|c|c|c|c|c|c|c|}
\hline \multirow[b]{3}{*}{ Variables } & \multicolumn{4}{|c|}{ Daily Minutes of Primary Child Care Time } & \multicolumn{4}{|c|}{ Daily Minutes of Passive Child Care Time } & \multicolumn{4}{|c|}{ Daily Minutes of Market Work Time } \\
\hline & \multicolumn{2}{|c|}{ Women } & \multicolumn{2}{|c|}{ Men } & \multicolumn{2}{|c|}{ Women } & \multicolumn{2}{|c|}{ Men } & \multicolumn{2}{|c|}{ Women } & \multicolumn{2}{|c|}{ Men } \\
\hline & Weekdays & Weekends & Weekdays & Weekends & Weekdays & Weekends & Weekdays & Weekends & Weekdays & Weekends & Weekdays & Weekends \\
\hline Own potential log wage & 15.4 & 14.3 & 0.1 & 25.1 & 20.0 & 69.3 & -35.9 & 65.0 & 238.4 & -4.4 & 19.9 & -70.0 \\
\hline Partner's potential log wage & 37.6 & 49.9 & 5.7 & 5.5 & -0.8 & 14.4 & 27.1 & 75.1 & -182.0 & 32.5 & 11.1 & -51.3 \\
\hline Youngest child age $0-3$ & 143.1 & 148.9 & 67.2 & 82.9 & 281.2 & 364.8 & 183.7 & 352.6 & -191.9 & -30.0 & 7.4 & 25.0 \\
\hline Youngest child age 4-6 & 96.6 & 95.7 & 51.1 & 52.1 & 174.1 & 352.8 & 147.3 & 350.0 & -2.5 & 2.7 & 50.1 & 22.6 \\
\hline Youngest child age 7-11 & 58.0 & 54.7 & 33.2 & 33.1 & 188.4 & 285.5 & 136.0 & 310.1 & -11.9 & -10.9 & 31.2 & -4.8 \\
\hline Total number of children & 12.4 & 0.7 & 2.5 & -0.7 & 44.1 & 16.2 & 19.5 & 6.6 & -69.3 & -10.1 & -35.3 & 1.5 \\
\hline Disabled child & 52.4 & 34.9 & -7.0 & 3.1 & 55.7 & 22.3 & 97.0 & -1.7 & -271.7 & 11.1 & -141.4 & 60.7 \\
\hline Respondent has a health problem & 7.6 & 6.1 & 13.1 & 1.6 & -22.4 & -20.9 & 10.6 & 49.9 & -144.2 & -3.5 & -287.9 & -99.3 \\
\hline Partner has a health problem & 4.5 & -5.9 & 2.8 & 5.4 & -20.2 & -26.5 & -23.7 & 13.0 & -169.2 & -10.6 & -22.4 & 2.9 \\
\hline Number of children $12-17$ & -13.1 & 1.3 & 3.0 & -0.2 & -2.1 & 39.9 & 10.3 & 23.1 & 40.2 & 3.0 & -6.2 & 16.5 \\
\hline Number of adults & -4.7 & -15.3 & -4.8 & -3.5 & -38.2 & -93.6 & -15.7 & -83.0 & -67.1 & -6.8 & -8.9 & -4.2 \\
\hline Cohabiting & -16.8 & -3.9 & -9.7 & -6.5 & -31.7 & -37.0 & -21.2 & -44.4 & 7.1 & -8.6 & -48.6 & 21.0 \\
\hline
\end{tabular}

Notes: Table reports selected marginal effects from the Tobit models of time use reported in Table 2. Estimated using sample means reported in Table 1 for UKTUS time use sample. 
Table 4. Coefficient Estimates from CLAD Models of Time-Use

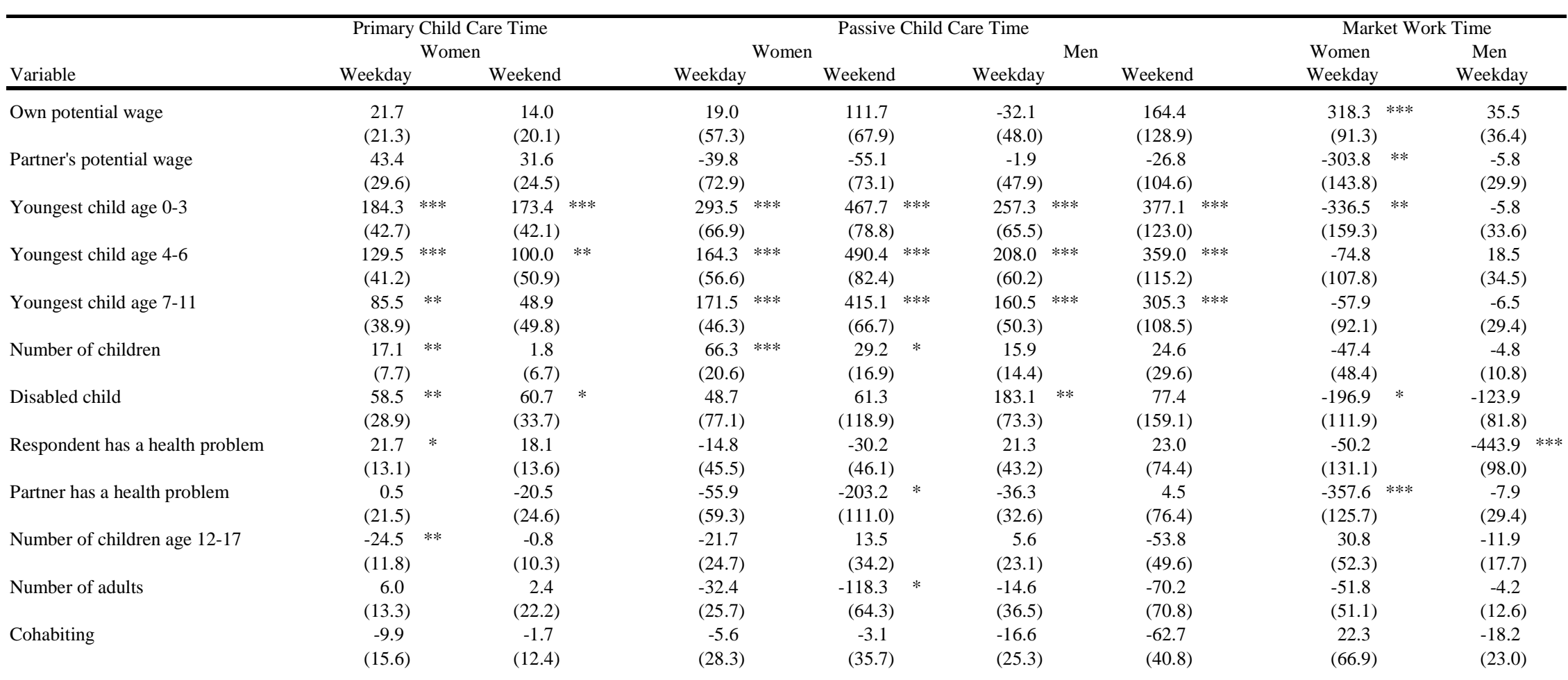

Notes: Table reports coefficients and standard errors (in parentheses) from CLAD models of time use. Estimated using data from the UKTUS.

Other variables included in all the specifications were quadratics in both own and partner's age, a dummy indicating household receipt of nonlabor income, a dummy indicating residence in a rural area, and seasonal indicators. A dummy variable identifying holidays is included in the weekend specifications.

* Significant at the $10 \%$ level, ** Significant at the 5\% level, *** Significant at the $1 \%$ level. 


\section{Appendix Table A1. Descriptive statistics for variables in wage sample}

\begin{tabular}{|c|c|c|c|c|}
\hline & \multicolumn{2}{|c|}{ Women } & \multicolumn{2}{|c|}{ Men } \\
\hline & Mean & Std. Err. & Mean & Std. Err. \\
\hline$\overline{\text { Employed }}$ & 0.7021 & $(0.4574)$ & 0.8047 & $(0.3965)$ \\
\hline Report a wage & 0.5327 & $(0.4990)$ & 0.5025 & $(0.5001)$ \\
\hline Log Wage (a) & 1.7135 & $(0.7601)$ & 1.8720 & $(0.8428)$ \\
\hline Cohabiting & 0.1036 & $(0.3048)$ & 0.1094 & $(0.3122)$ \\
\hline Single & 0.3411 & $(0.4742)$ & 0.2950 & $(0.4561)$ \\
\hline First or post-graduate degree & 0.1144 & $(0.3184)$ & 0.1238 & $(0.3294)$ \\
\hline Other degree & 0.0252 & $(0.1568)$ & 0.0524 & $(0.2228)$ \\
\hline Some higher education, no degree & 0.1330 & $(0.3397)$ & 0.0912 & $(0.2880)$ \\
\hline "A" level or vocational level 3 & 0.1018 & $(0.3024)$ & 0.1395 & $(0.3465)$ \\
\hline "O” level, gcse grade a-c, or vocational level 2 & 0.2018 & $(0.4014)$ & 0.1549 & $(0.3618)$ \\
\hline gcse below grade $\mathrm{c}, \mathrm{cse}$, or vocational level 1 & 0.0408 & $(0.1980)$ & 0.0361 & $(0.1864)$ \\
\hline Other qualifications & 0.0399 & $(0.1958)$ & 0.0567 & $(0.2314)$ \\
\hline Age & 38.3688 & $(11.4842)$ & 40.7056 & $(12.8244)$ \\
\hline Potential experience & 20.9009 & $(11.9232)$ & 23.1749 & $(13.2129)$ \\
\hline Respondent has a health problem & 0.1297 & $(0.3361)$ & 0.1270 & $(0.3330)$ \\
\hline Youngest child age $0-3$ & 0.1495 & $(0.3567)$ & 0.1216 & $(0.3269)$ \\
\hline Youngest child age 4-6 & 0.0748 & $(0.2631)$ & 0.0558 & $(0.2296)$ \\
\hline Youngest child age $7-11$ & 0.1309 & $(0.3374)$ & 0.1031 & $(0.3042)$ \\
\hline Total number of children & 0.8736 & $(1.1035)$ & 0.7094 & $(1.0479)$ \\
\hline Number of children $12-17$ & 0.6500 & $(0.8187)$ & 0.6354 & $(0.8042)$ \\
\hline Disabled child & 0.0138 & $(0.1167)$ & 0.0075 & $(0.0864)$ \\
\hline Number of adults & 0.4850 & $(0.8995)$ & 0.5113 & $(0.9104)$ \\
\hline Household receives unearned income & 0.2264 & $(0.4186)$ & 0.2420 & $(0.4284)$ \\
\hline Unemployment rate & 6.8877 & $(3.7941)$ & 6.7864 & $(3.7317)$ \\
\hline Rural & 0.4306 & $(0.4952)$ & 0.4461 & $(0.4972)$ \\
\hline Northeast & 0.0471 & $(0.2120)$ & 0.0414 & $(0.1992)$ \\
\hline Northwest & 0.1120 & $(0.3154)$ & 0.1160 & $(0.3203)$ \\
\hline Yorkshire \& Humberside \& East Midlands & 0.1991 & $(0.3994)$ & 0.1940 & $(0.3955)$ \\
\hline West Midlands & 0.0772 & $(0.2669)$ & 0.0812 & $(0.2732)$ \\
\hline East & 0.0979 & $(0.2972)$ & 0.1056 & $(0.3074)$ \\
\hline South East (except London) & 0.1282 & $(0.3344)$ & 0.1313 & $(0.3378)$ \\
\hline South West & 0.1018 & $(0.3024)$ & 0.0962 & $(0.2950)$ \\
\hline Wales & 0.0471 & $(0.2120)$ & 0.0505 & $(0.2189)$ \\
\hline Scotland & 0.1066 & $(0.3087)$ & 0.1063 & $(0.3082)$ \\
\hline Winter & 0.2384 & $(0.4262)$ & 0.2335 & $(0.4232)$ \\
\hline Spring & 0.2634 & $(0.4405)$ & 0.2661 & $(0.4420)$ \\
\hline Summer & 0.2270 & $(0.4190)$ & 0.2398 & $(0.4270)$ \\
\hline Partner: First or post-graduate degree & 0.0838 & $(0.2771)$ & 0.0787 & $(0.2693)$ \\
\hline Partner: Other degree & 0.0360 & $(0.1864)$ & 0.0166 & $(0.1278)$ \\
\hline Partner: Some higher education, no degree & 0.0658 & $(0.2479)$ & 0.0972 & $(0.2962)$ \\
\hline Partner: "A" level or vocational level 3 & 0.0934 & $(0.2910)$ & 0.0693 & $(0.2540)$ \\
\hline Partner: "O" level, gcse grade a-c, or vocational & & & & \\
\hline level 2 & 0.0958 & $(0.2944)$ & 0.1364 & $(0.3432)$ \\
\hline $\begin{array}{l}\text { Partner: gcse below grade c, cse, or vocational } \\
\text { level } 1\end{array}$ & 0.0207 & $(0.1425)$ & 0.0254 & $(0.1573)$ \\
\hline Partner: Other qualifications & 0.0420 & $(0.2007)$ & 0.0270 & $(0.1620)$ \\
\hline Partner's age & 28.6754 & $(22.5138)$ & 29.2865 & $(21.0584)$ \\
\hline Partner's potential experience & 17.1309 & $(15.4610)$ & 16.9937 & $(14.6288)$ \\
\hline Partner has a health problem & 17.1309 & $(15.4610)$ & 16.9937 & $(14.6288)$ \\
\hline Number of observations & 3330 & & 3190 & \\
\hline
\end{tabular}


Appendix Table A2. Full sample sample selection controlled probits on wage reporting

\begin{tabular}{|c|c|c|c|c|c|c|c|c|}
\hline & & Won & & & & $\mathrm{Mel}$ & & \\
\hline & Wage Report & & Employed & & Wage Report & & Employed & \\
\hline Cohabiting & $\begin{array}{c}0.0486 \\
(0.1062)\end{array}$ & & $\begin{array}{c}0.0925 \\
(0.1001)\end{array}$ & & $\begin{array}{l}-0.1525 \\
(0.0882)\end{array}$ & $*$ & $\begin{array}{l}-0.3940 \\
(0.1213)\end{array}$ & $* * *$ \\
\hline Single & $\begin{array}{c}0.0783 \\
(0.0896)\end{array}$ & & $\begin{array}{c}0.2597 \\
(0.9094)\end{array}$ & & $\begin{array}{l}-0.1181 \\
(0.0959)\end{array}$ & & $\begin{array}{c}0.3853 \\
(1.3292)\end{array}$ & \\
\hline First or post-graduate degree & $\begin{array}{c}0.3036 \\
(0.1688)\end{array}$ & $*$ & $\begin{array}{c}0.7164 \\
(0.1220)\end{array}$ & $* * *$ & $\begin{array}{c}0.5762 \\
(0.1122)\end{array}$ & $* * *$ & $\begin{array}{c}0.1175 \\
(0.1436)\end{array}$ & \\
\hline Other degree & $\begin{array}{l}-0.4709 \\
(0.1940)\end{array}$ & $* *$ & $\begin{array}{c}0.6818 \\
(0.1988)\end{array}$ & $* * *$ & $\begin{array}{l}-0.2373 \\
(0.1239)\end{array}$ & $*$ & $\begin{array}{c}0.2308 \\
(0.1841)\end{array}$ & \\
\hline Some higher education, no degree & $\begin{array}{c}0.0823 \\
(0.1354)\end{array}$ & & $\begin{array}{c}0.5647 \\
(0.0906)\end{array}$ & $* * *$ & $\begin{array}{c}0.2751 \\
(0.0952)\end{array}$ & $* * *$ & $\begin{array}{c}0.1513 \\
(0.1197)\end{array}$ & \\
\hline "A" level or vocational level 3 & $\begin{array}{c}0.0608 \\
(0.1302)\end{array}$ & & $\begin{array}{c}0.4002 \\
(0.0945)\end{array}$ & $* * *$ & $\begin{array}{c}0.2573 \\
(0.0819)\end{array}$ & $* * *$ & $\begin{array}{c}0.2931 \\
(0.1042)\end{array}$ & $* * *$ \\
\hline “O” level, gcse grade a-c, or vocational level 2 & $\begin{array}{c}0.3003 \\
(0.1216)\end{array}$ & $* *$ & $\begin{array}{c}0.4248 \\
(0.0752)\end{array}$ & $* * *$ & $\begin{array}{c}0.2907 \\
(0.0793)\end{array}$ & $* * *$ & $\begin{array}{c}0.1524 \\
(0.0937)\end{array}$ & \\
\hline gcse below grade c, cse, or vocational level 1 & $\begin{array}{c}0.4315 \\
(0.1831)\end{array}$ & $* *$ & $\begin{array}{c}0.2112 \\
(0.1320)\end{array}$ & & $\begin{array}{c}0.2220 \\
(0.1372)\end{array}$ & & $\begin{array}{c}0.3961 \\
(0.1882)\end{array}$ & $* *$ \\
\hline Other qualifications & $\begin{array}{l}-0.1685 \\
(0.1614)\end{array}$ & & $\begin{array}{c}0.3507 \\
(0.1340)\end{array}$ & $* * *$ & $\begin{array}{l}-0.0897 \\
(0.1178)\end{array}$ & & $\begin{array}{c}0.0961 \\
(0.1333)\end{array}$ & \\
\hline Age & $\begin{array}{c}0.0675 \\
(0.0609)\end{array}$ & & $\begin{array}{c}0.1379 \\
(0.0496)\end{array}$ & $* * *$ & $\begin{array}{c}0.0976 \\
(0.0450)\end{array}$ & $* *$ & $\begin{array}{c}0.2245 \\
(0.0478)\end{array}$ & $* * *$ \\
\hline Age squared & $\begin{array}{l}-0.0011 \\
(0.0008)\end{array}$ & & $\begin{array}{l}-0.0022 \\
(0.0007)\end{array}$ & $* * *$ & $\begin{array}{l}-0.0018 \\
(0.0005)\end{array}$ & $* * *$ & $\begin{array}{l}-0.0029 \\
(0.0006)\end{array}$ & $* * *$ \\
\hline Potential experience & $\begin{array}{l}-0.0048 \\
(0.0306)\end{array}$ & & $\begin{array}{l}-0.0028 \\
(0.0284)\end{array}$ & & $\begin{array}{l}-0.0171 \\
(0.0247)\end{array}$ & & $\begin{array}{l}-0.0366 \\
(0.0309)\end{array}$ & \\
\hline Potential experience squared & $\begin{array}{c}0.0005 \\
(0.0007)\end{array}$ & & $\begin{array}{c}0.0005 \\
(0.0006)\end{array}$ & & $\begin{array}{c}0.0011 \\
(0.0005)\end{array}$ & $* *$ & $\begin{array}{c}0.0007 \\
(0.0005)\end{array}$ & \\
\hline Respondent has a health problem & $\begin{array}{c}0.2495 \\
(0.2334)\end{array}$ & & $\begin{array}{l}-0.9859 \\
(0.0724)\end{array}$ & $* * *$ & $\begin{array}{l}-0.2679 \\
(0.1925)\end{array}$ & & $\begin{array}{l}-1.4898 \\
(0.0823)\end{array}$ & $* * *$ \\
\hline Youngest child age $0-3$ & $\begin{array}{c}0.1817 \\
(0.2098)\end{array}$ & & $\begin{array}{l}-0.7156 \\
(0.1285)\end{array}$ & $* * *$ & $\begin{array}{c}0.1255 \\
(0.1442)\end{array}$ & & $\begin{array}{c}0.2401 \\
(0.2221)\end{array}$ & \\
\hline Youngest child age 4-6 & $\begin{array}{l}-0.0935 \\
(0.1957)\end{array}$ & & $\begin{array}{l}-0.2986 \\
(0.1416)\end{array}$ & $* *$ & $\begin{array}{c}0.0745 \\
(0.1655)\end{array}$ & & $\begin{array}{c}0.2950 \\
(0.2380)\end{array}$ & \\
\hline Youngest child age 7-11 & $\begin{array}{c}0.0046 \\
(0.1493)\end{array}$ & & $\begin{array}{l}-0.1684 \\
(0.1122)\end{array}$ & & $\begin{array}{c}0.0023 \\
(0.1235)\end{array}$ & & $\begin{array}{c}0.2063 \\
(0.1788)\end{array}$ & \\
\hline Total number of children & $\begin{array}{l}-0.0483 \\
(0.0992)\end{array}$ & & $\begin{array}{l}-0.2687 \\
(0.0562)\end{array}$ & $* * *$ & $\begin{array}{l}-0.1375 \\
(0.0652)\end{array}$ & $* *$ & $\begin{array}{l}-0.2531 \\
(0.0900)\end{array}$ & $* * *$ \\
\hline Number of children $12-17$ & $\begin{array}{c}0.0011 \\
(0.1026)\end{array}$ & & $\begin{array}{c}0.2031 \\
(0.0695)\end{array}$ & $* * *$ & $\begin{array}{c}0.0817 \\
(0.0761)\end{array}$ & & $\begin{array}{c}0.2212 \\
(0.1061)\end{array}$ & $* *$ \\
\hline Disabled child & $\begin{array}{c}0.4927 \\
(0.3321)\end{array}$ & & $\begin{array}{l}-0.1118 \\
(0.2089)\end{array}$ & & $\begin{array}{c}0.2893 \\
(0.2889)\end{array}$ & & $\begin{array}{c}0.5449 \\
(0.4328)\end{array}$ & \\
\hline Number of adults & $\begin{array}{l}-0.0989 \\
(0.0382)\end{array}$ & $* * *$ & $\begin{array}{c}0.0825 \\
(0.0351)\end{array}$ & $* *$ & $\begin{array}{l}-0.0883 \\
(0.0344)\end{array}$ & $* *$ & $\begin{array}{c}0.0593 \\
(0.0386)\end{array}$ & \\
\hline Household receives unearned income & $\begin{array}{l}-0.0780 \\
(0.0707)\end{array}$ & & $\begin{array}{c}0.0758 \\
(0.0653)\end{array}$ & & $\begin{array}{c}0.0120 \\
(0.0610)\end{array}$ & & $\begin{array}{l}-0.0140 \\
(0.0770)\end{array}$ & \\
\hline Unemployment rate & $\begin{array}{c}0.0106 \\
(0.0127)\end{array}$ & & $\begin{array}{l}-0.0462 \\
(0.0076)\end{array}$ & $* * *$ & $\begin{array}{l}-0.0075 \\
(0.0085)\end{array}$ & & $\begin{array}{l}-0.0320 \\
(0.0086)\end{array}$ & $* * *$ \\
\hline Rural & $\begin{array}{l}-0.0915 \\
(0.0700)\end{array}$ & & $\begin{array}{l}-0.1270 \\
(0.0590)\end{array}$ & $* *$ & $\begin{array}{l}-0.1085 \\
(0.0571)\end{array}$ & $*$ & $\begin{array}{l}-0.0341 \\
(0.0707)\end{array}$ & \\
\hline
\end{tabular}




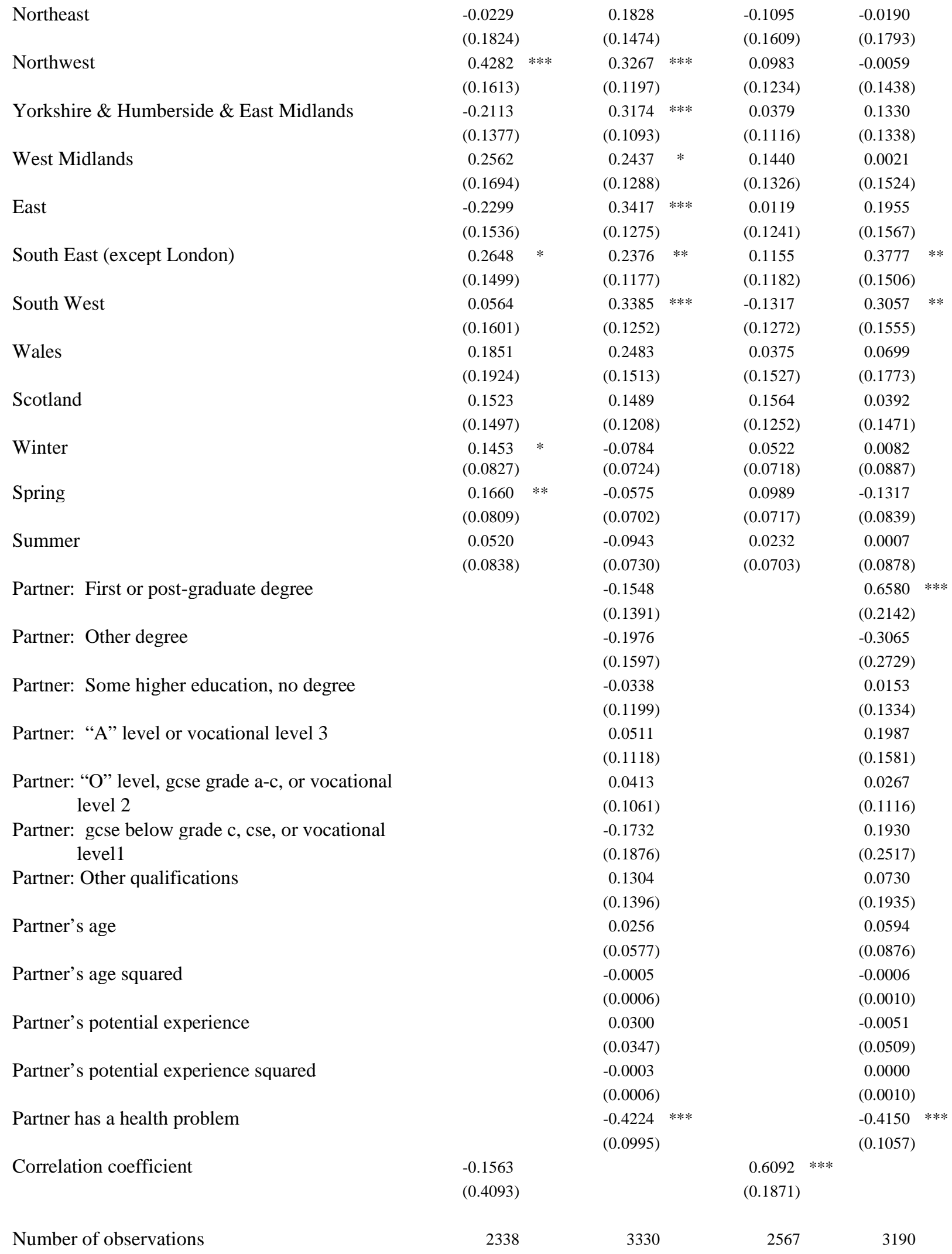

Notes: Table reports coefficients and standard errors (in parentheses) estimated using data from the UKTUS.

* Significant at the $10 \%$ level, ** Significant at the 5\% level, *** Significant at the $1 \%$ level. 
Appendix Table A3. Full sample log wage regression results

\begin{tabular}{|c|c|c|c|c|c|c|}
\hline & \multicolumn{2}{|c|}{ Women } & \multicolumn{4}{|c|}{ Men } \\
\hline & Coefficient & (Std. error) & & Coefficient & (Std. error) & \\
\hline Cohabiting & 0.0264 & $(0.0375)$ & & 0.0549 & $(0.0709)$ & \\
\hline Single & 0.0376 & $(0.0370)$ & & -0.1202 & $(0.0579)$ & ** \\
\hline First or post-graduate degree & 0.5116 & $(0.0894)$ & $\star \star \star \star ~$ & 0.2011 & $(0.2324)$ & \\
\hline Other degree & 0.2495 & $(0.1538)$ & & 0.4078 & $(0.1264)$ & $* \star *$ \\
\hline Some higher education, no degree & 0.2805 & $(0.0511)$ & $* \star *$ & 0.1352 & $(0.1235)$ & \\
\hline "A" level or vocational level 3 & 0.1399 & $(0.0474)$ & $\star \star \star *$ & 0.1128 & $(0.1144)$ & \\
\hline $\begin{array}{l}\text { "O” level, gcse grade a-c, or } \\
\text { vocational level } 2\end{array}$ & 0.1311 & $(0.0773)$ & * & 0.0161 & $(0.1261)$ & \\
\hline $\begin{array}{l}\text { gcse below grade c, cse, or } \\
\quad \text { vocational level } 1\end{array}$ & 0.0247 & $(0.1092)$ & & -0.0430 & $(0.1101)$ & \\
\hline Other qualifications & 0.0032 & $(0.0793)$ & & 0.0438 & $(0.0738)$ & \\
\hline Age & -0.0285 & $(0.0266)$ & & -0.0051 & $(0.0420)$ & \\
\hline Age squared & 0.0008 & $(0.0004)$ & ** & 0.0007 & $(0.0008)$ & \\
\hline Potential experience & 0.0284 & $(0.0113)$ & ** & 0.0117 & $(0.0112)$ & \\
\hline Potential experience squared & -0.0014 & $(0.0003)$ & $* \star \star$ & -0.0011 & $(0.0004)$ & $\star \star$ \\
\hline Respondent has a health problem & -0.0208 & $(0.0956)$ & & -0.1050 & $(0.1395)$ & \\
\hline Youngest child age $0-3$ & 0.2266 & $(0.0813)$ & 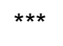 & -0.0235 & $(0.0775)$ & \\
\hline Youngest child age 4-6 & 0.0509 & $(0.0731)$ & & -0.0725 & $(0.0756)$ & \\
\hline Youngest child age $7-11$ & -0.0063 & $(0.0513)$ & & 0.0169 & $(0.0519)$ & \\
\hline Total number of children & -0.0478 & $(0.0353)$ & & 0.0191 & $(0.0624)$ & \\
\hline Number of children $12-17$ & 0.0129 & $(0.0358)$ & & -0.0216 & $(0.0469)$ & \\
\hline Disabled child & 0.0855 & $(0.1387)$ & & -0.0602 & $(0.1645)$ & \\
\hline Number of adults & -0.0458 & $(0.0275)$ & * & -0.0027 & $(0.0383)$ & \\
\hline Household receives unearned & & & & & & \\
\hline income & -0.0030 & $(0.0315)$ & & 0.0646 & $(0.0260)$ & ** \\
\hline Unemployment rate & 0.0010 & $(0.0050)$ & & -0.0176 & $(0.0046)$ & $* * *$ \\
\hline Rural & -0.0556 & $(0.0321)$ & * & -0.0386 & $(0.0510)$ & \\
\hline Northeast & -0.1869 & $(0.0657)$ & $* * *$ & -0.1975 & $(0.0825)$ & ** \\
\hline Northwest & -0.0687 & $(0.1038)$ & & -0.1590 & $(0.0649)$ & ** \\
\hline Yorkshire \& Humberside \& East & & & & & & \\
\hline Midlands & -0.2717 & $(0.0742)$ & $\star \star \star *$ & -0.1393 & $(0.0497)$ & $* \star *$ \\
\hline West Midlands & -0.1251 & $(0.0793)$ & & -0.1535 & $(0.0793)$ & * \\
\hline East & -0.1855 & $(0.0838)$ & ** & -0.0624 & $(0.0530)$ & \\
\hline South East (except London) & -0.0327 & $(0.0781)$ & & -0.1063 & $(0.0677)$ & \\
\hline South West & -0.2069 & $(0.0569)$ & $* \star \star$ & -0.0811 & $(0.0809)$ & \\
\hline Wales & -0.2440 & $(0.0793)$ & $* \star *$ & -0.1423 & $(0.0676)$ & ** \\
\hline Scotland & -0.1474 & $(0.0626)$ & ** & -0.2011 & $(0.0828)$ & $\star *$ \\
\hline Winter & 0.0544 & $(0.0457)$ & & 0.0332 & $(0.0372)$ & \\
\hline Spring & 0.0869 & $(0.0480)$ & * & 0.0362 & $(0.0496)$ & \\
\hline Summer & 0.0396 & $(0.0334)$ & & 0.0174 & $(0.0316)$ & \\
\hline Correction for employment & 0.5288 & $(0.5348)$ & & -0.4024 & $(0.7309)$ & \\
\hline Correction for wage reporting & -0.0863 & $(0.1316)$ & & -0.0913 & $(0.3058)$ & \\
\hline Constant & 1.5210 & $(0.5804)$ & $\star * *$ & 1.8770 & $(0.9596)$ & * \\
\hline Number of observations & 1774 & & & 1603 & & \\
\hline
\end{tabular}

Note: Coefficients and standard errors (in parentheses) from dual sample selection controlled $\log$ wage regressions estimated using data from the UKTUS.

* Significant at the $10 \%$ level, ** Significant at the 5\% level, *** Significant at the $1 \%$ level. 
Endnotes

${ }^{1}$ Authors' calculation from Statistics UK data.

2 There is a related sociological literature that has examined how the provision of child care is related to own and partners' work hours. For example, Nock and Kingston (1988) found that the amount of time that married parents spend in different types of child care activities is sensitive to each parent's work schedule. Bryant and Zick (1996) found that increases in mothers' work times only modestly reduced the time they spent in family care and did not affect the time that fathers spent in this activity. Bianchi (2000) has reported surprising evidence that mothers' time spent with children has increased slightly over time, even as more mothers have entered the labor force.

3 The UKTUS does not identify the specific people who are present during an activity. Instead, for most activities it lists categories of people present, including household children up to age 9, household children ages 10-14, other household members, and other known persons.

${ }^{4}$ Estimates from alternative time use specifications that rely only on the unemployment rate and regional controls for identification of wage effects are similar to those that we report but less precise. 